\title{
Lysis of Non-marine Fungi by Marine Micro-organisms
}

\author{
By R. MITCHELL AND C. WIRSEN \\ Laboratory of Applied Microbiology, Division of Engineering and Applied \\ Physics, Harvard University, Cambridge, Mass., U.S.A.
}

(Accepted for publication I9 January 1968)

\begin{abstract}
S U M M A R Y
A number of non-marine Oomycetes and a marine-isolated Pythium culture were lysed in natural sea water by marine micro-organisms. A relationship was observed between the rate and extent of lysis and the size of the marine microbial population. Microscopic observations and the accumulation of reducing sugars indicated that extracellular cell wall-lysing enzymes were responsible. Pure cultures of lytic bacteria isolated from the sea yielded data similar to those obtained in natural sea water. The importance of the lytic phenomenon in the determination of the marine mycoflora is discussed.
\end{abstract}

\section{INTRODUCTION}

In the field of marine mycology it is necessary to investigate the biochemical activities of fungi in the oceans before we can understand their ecological significance and their distinct characters. The mycoflora of the oceans has not been studied in enough detail to identify marine-isolated fungi as specific halophiles, salt-adapted species, or non-marine fungi capable of survival in sea water (Johnson \& Sparrow, 1961). MacLeod \& Onofrey (1963) and ZoBell (1946) showed that some marine bacteria could develop the capacity to grow in the presence of reduced salt concentrations or even in freshwater media. Thus we may ask if some freshwater fungi adapt to marine conditions while others are eradicated by a biological process.

Previous data from our laboratory have shown that a specific marine microflora capable of killing Escherichia coli develops when that bacterium is added to sea water (Mitchell, Yankofsky \& Jannasch, 1967). The presence in soil of micro-organisms capable of killing non-indigenous fungi by lysing their cell walls is well documented (Mitchell \& Alexander, 1963). The present paper describes results obtained when a fungus whose habitat is soil was added to sea water. The fungus Pythium debaryanum was used because of the detailed information available about its cell-wall structure (Cooper \& Aronson, 1967).

\section{METHODS}

In the current study the representative Phycomycete used was Pythium debaryanum ATCC9998. Other Oomycetes used were Saprolegnia diclina, Achlya caroliniania, Isoachlya luxuriana, Thraustotheca clavata and Apodachlya brachynema. Fungal mats were grown in Petri dishes using a potato dextrose broth at $23^{\circ}$, and were washed with $200 \mathrm{ml}$. sterile water before use.

The sea water used was sampled at Woods Hole and at Nahant, Mass. When not used immediately it was stored at $3^{\circ}$. For pure culture studies artificial sea water (Lyman \& Fleming, 1940) was used. 
Marine bacteria were isolated on modified 22I6E agar medium (Oppenheimer \& ZoBell, I952) and were grown in liquid $2216 \mathrm{E}$ medium in $250 \mathrm{ml}$. Erlenmeyer flasks at $23^{\circ}$.

Degradation studies of Pythium debaryanum in both natural sea water and by pure cultures were carried out in $250 \mathrm{ml}$. Erlenmeyer flasks at $25^{\circ}$ on a new Brunswick (Model G Io) gyratory shaker. Mycelial mat weight was determined following collection of the fungus by filtration and drying at $110^{\circ}$, always in triplicate.

Cell-free filtrates were obtained after degradation of the mat in natural sea water by centrifuging for $10 \mathrm{~min}$. at $7000 \mathrm{~g}$ and then aseptically filtering through $0.45 \mu$ Millipore filters.

Some of the sea-water filtrate was concentrated by reducing the volume in a reverse osmosis ultrafiltration cell. Molecules with a molecular weight greater than 10,000 are retained by the UM-I ultrafiltration membrane. The apparatus (Diaflo Model 50 cell) and membranes were obtained from the Amicon Corp., Cambridge, Mass. Enzymic activity of the filtrates was tested against washed Pythium mycelium by assaying for release of reducing sugars by the anthrone method (Dische, 1955). Enrichment cultures were employed using Pythium cell walls prepared in a modified French press (Raper \& Hyatt, 1963).

\section{RESULTS}

\section{Effect of the marine microflora on Pythium mycelium}

In order to study the effect of the native marine microflora on Pythium mycelium, mycelial mats were added to sterile and non-sterile sea water. The mats remained intact in the sterile sea water, but were slowly degraded in static culture at $23^{\circ}$ in fresh non-sterile sea water. Total degradation usually occurred 26 days after inoculation of the fungus.

The development of a specific antagonistic marine microflora was demonstrated by adding washed Pythium mycelial mats to fresh natural sea water, to autoclaved sea water, and to Millipore-filtered $(0.22 \mu)$ sea water. The mycelia shaken in natural sea water completely disintegrated in 12 days, whereas in autoclaved and filtered sea water the mycelium was unaffected (Fig. I).

When a second Pythium inoculum was placed in the flasks following degradation and subsequent removal of the remaining first mycelial mat, the second mat degraded, but much more rapidly, the time of degradation being 6 days (Fig. I).

These data indicate either that the first Pythium inoculum stimulated the development of an antagonistic microflora which rapidly degraded the second inoculum of the fungus, or that an inducible enzyme system was stimulated.

\section{Effect of $p H$, nutrients and dilution on the degradation of mycelium}

Mycelial mats were placed in filter-sterilized sea water adjusted to $\mathrm{pH}$ values of 4,5 , 8 and 9. A loopful of inoculum from a Pythium culture being actively degraded in sea water was added to each flask. After 7 days the mats at $\mathrm{pH} 5,8$ and 9 showed signs of degradation, with the most extensive degradation occurring at $\mathrm{pH} 8$. There was no degradation at $\mathrm{pH} 4$ and the mats remained intact. It was observed that when 10 p.p.m. of 100 p.p.m. yeast extract was added to sea water along with a Pythium mat, the degradation process was accelerated. The process was accelerated even more when 
yeast extract was added to the sea water 2 days before addition of the fungus, indicating that a stimulation of the native marine microbial population accelerated fungal lysis.

An indirect effect of bacterial population size was shown by dilution of the natural sea water. Sea water was sterilized by Millipore-filtration $(0.22 \mu)$. The undiluted samples contained $100 \mathrm{ml}$. natural sea water. The $\mathrm{r} / \mathrm{IO}$ dilution contained $90 \mathrm{ml}$. filter-sterilized sea water and $10 \mathrm{ml}$. natural sea water. The I/100 dilution contained $99 \mathrm{ml}$. filter-sterilized sea water and $\mathrm{I} \cdot 0 \mathrm{ml}$. natural sea water. The time required for the degradation of fungal mats added to the flasks was followed by measuring mycelial mat weight. The mats in undiluted sea water displayed visible degradation after 4 days

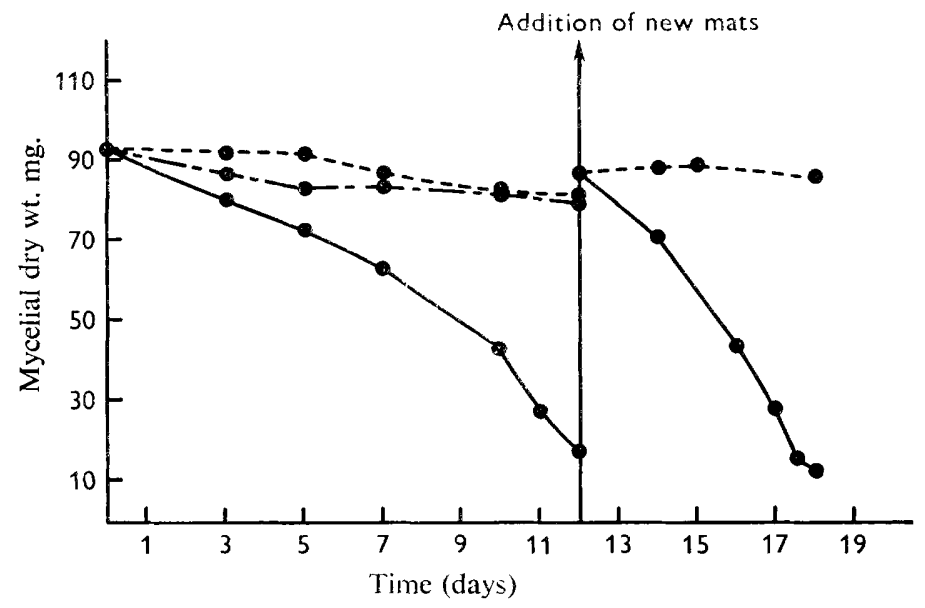

Fig. I. Effect of repeated additions of mycelial mats on lysis of Pythium debaryanum mycelium in natural sea water. __ Natural sea water, -- -, autoclaved sea water; - - - Milliporefiltered $(0 \cdot 22 \mu$ sea water).

and were totally degraded after 8 days; the mats in I/Io dilution began to lyse after 7 days and were totally degraded after 12 days; the mats in the $1 / 100$ dilution began to lyse after 9 days and were totally degraded after 17 days. These data provide further evidence that the degradation of Pythium is directly proportional to the size of the native marine microbial population.

\section{Tests for enzymic activity}

In subsequent experiments the ability of cell-free filtrates of sea water to degrade Pythium mycelium enzymically was tested. We used sea water which had been exposed to and had degraded two consecutive Pythium inocula, so as to obtain maximal activity. When the second inoculum was completely degraded the sea water was centrifuged for $20 \mathrm{~min}$. at $7000 \mathrm{~g}$ and filtered aseptically through $0.45 \mu$ Millipore filters. Some of the sea water filtrate was concentrated by reducing the volume in a reverse osmosis ultrafiltration cell. Molecules with a molecular weight greater than I 0,000 were retained by the ultrafiltration membrane used in this study. Concentration of these molecules was achieved within approximately $\mathrm{I} \mathrm{hr}$ in a single step using this method.

The concentrated and unconcentrated cell-free filtrates were tested for enzymic 
activity against intact washed Pythium mycelium. The results obtained (Fig. 2) show that reducing sugars, measured as $\mu \mathrm{g}$. glucose $/ \mathrm{ml}$, , were released within $\mathrm{I}$ hr after addition of the mycelium to unconcentrated filtrate. The activity was substantially increased in the concentrated filtrate. The system was inactivated by heating the filtrate to $100^{\circ}$ for $15 \mathrm{~min}$. These data indicate the presence of extracellular lytic enzymes produced by marine micro-organisms which suppressed the non-marine fungus.

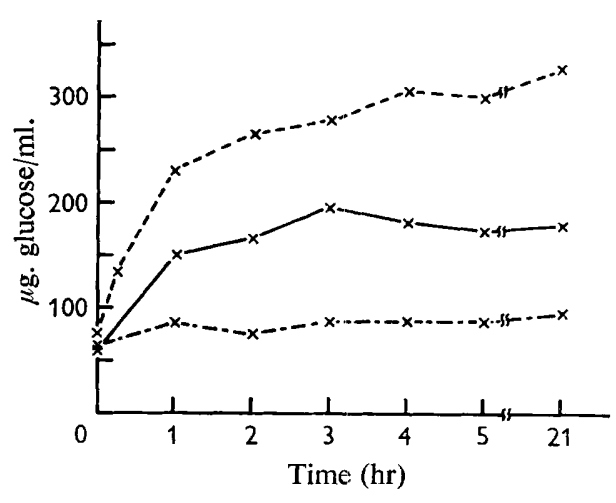

Fig. 2

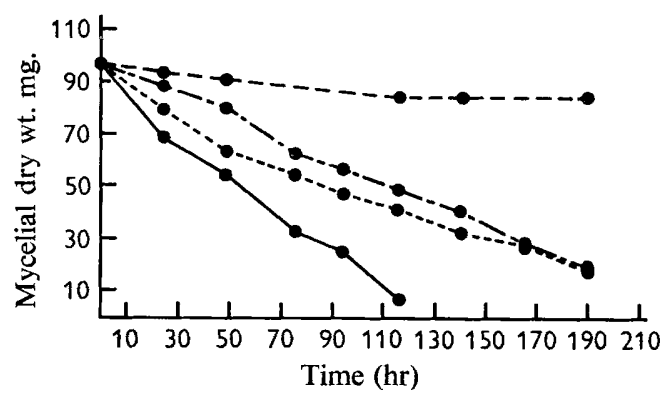

Fig. 3

Fig. 2. Release of reducing sugars during lysis of Pythium debaryanum mycelium by filtered sea water. The sea water was subjected to repeated inoculation with Pythium before filtration. - - Unconcentrated filtrate; - - -, concentrated (I I. $5 \times$ ) filtrate; - - - , boiled filtrate.

Fig. 3. Relationship between the numbers of lytic bacteria present and the rate of lysis of Pythium debaryanum. - - , Autoclaved sea water; - - , sea water and $10^{4}$ bacteria $/ \mathrm{ml}$. added; - - -, sea water and $10^{5}$ bacteria/ml. added; __, sea water and $10^{6}$ bacteria/ml. added.

\section{Pure culture studies}

Isolations of marine bacteria were made from sea water to $2216 \mathrm{E}$ media following degradation of a mycelial mat. A bacterium, tentatively identified as an Agarbacterium sp. which would degrade Pythium in pure culture, was isolated from sea water enriched with Pythium cell walls. This bacterium yielded results similar to those observed in natural sea water. However, the degradation time was more rapid in pure culture. Fig. 3 shows data indicating that when the cell concentration of Agarbacterium sp. added to artificial sea water was $10^{4} / \mathrm{ml}$, the fungal mat was degraded in $190 \mathrm{hr}$. When the concentration was $10^{6} / \mathrm{ml}$., degradation occurred in $116 \mathrm{hr}$. A higher level of antifungal activity was detected following repeated inoculation of the fungus. When a fungal mat was added to artificial sea water inoculated with $10^{6} / \mathrm{ml}$. Agarbacterium sp., the mat was degraded in I $5 \mathrm{hr}$, whereas the second inoculum of the fungus was degraded by the bacteria in $75 \mathrm{hr}$ (Fig. 4). Many spheroplasts of the fungus were observed under phase-contrast microscopy during the course of degradation, suggesting that lysis of the fungal cell walls was occurring.

\section{Comparison of lysis of a marine-isolated Pythium with Pythium debaryanum}

Mycelial mats of Pythium debaryanum grown in potato dextrose broth were washed and added to flasks containing $100 \mathrm{ml}$. autoclaved sea water and to flasks containing 
$100 \mathrm{ml}$. of natural sea water. The same procedure was followed for a marine isolate of Pythium. The marine species was grown in potato dextrose broth prepared with $75 \%$ sea water. Mycelial mat weights were determined, in triplicate, during degradation. The results presented in Fig. 5 show that in the time period tested the mycelial stage of the marine isolate was as susceptible to degradation by the marine microflora as Pythium debaryanum. This may imply salt adaptation on the part of the marine isolate with no or very slight changes in its cell-wall structure, thus giving it no competitive advantage over the freshwater strain.

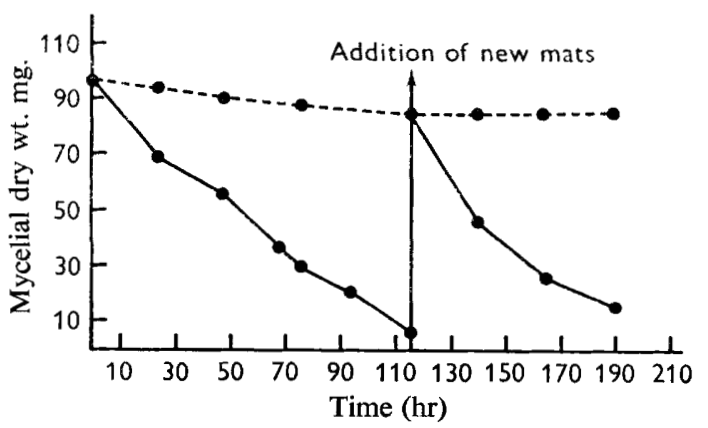

Fig. 4

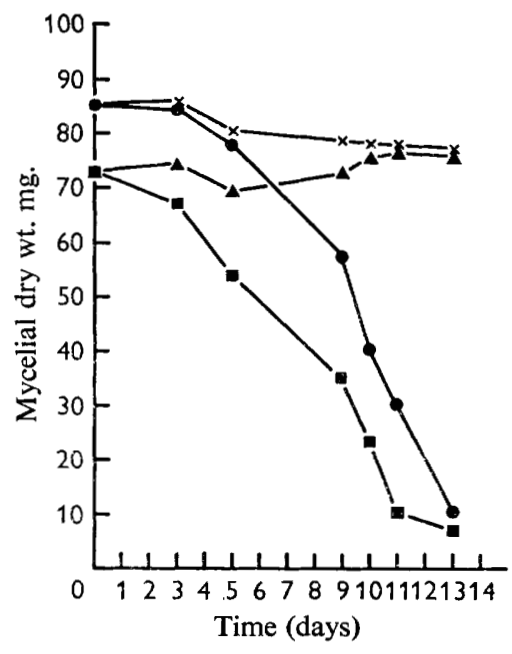

Fig. 5

Fig. 4. The effect of repeated additions of mycelium on degradation of Pythium debaryanum by a lytic bacterium isolated from the sea. ---, Autoclaved sea water and $10^{6}$ bacteria $/ \mathrm{ml}$. added. Fig. 5. A comparison of the rates of lysis in natural sea water of a freshwater strain and a marine-isolated Pythium strain. $\mathbf{\Delta}-\mathbf{\Delta}$, Salt water Pythium control; $\mathbf{0}-\mathbf{n}$, salt water Pythium test; $\times-\times$, freshwater Pythium control; - , freshwater Pythium test.

The effect of salt adaptation on the susceptibility to lysis of the non-marine Pythium was tested by first adapting Pythium debaryanum to grow in potato dextrose broth prepared in $80 \%$ artificial sea water. This was achieved by a series of serial transfers to Io, 20, 40,60,70 and $80 \%$ artificial sea water. The fungus was then tested for resistance to degradation. It was observed that the salt-adapted Pythium debaryanum was degraded as rapidly as the non-adapted $P$. debaryanum both in natural sea water and in artificial sea water with $10^{6} / \mathrm{ml}$. Agarbacterium sp. added.

\section{Degradation studies of other Oomycetes}

Five isolates of closely related Oomycetes were tested for resistance to degradation in natural sea water and also to degradation by the Pythium-degrading bacterium. The isolates were Apodachlya brachynema, Saprolegnia diclina, Achlya caroliniania, Isoachlya luxuriana and Thraustotheca clavata. Mycelial mats of these fungi were grown in potato dextrose broth, collected, washed, and added to $100 \mathrm{ml}$. natural sea water and to $100 \mathrm{ml}$. autoclaved sea water in $250 \mathrm{ml}$. Erlenmeyer flasks. All of the mats in natural sea water turned yellowish and were entirely degraded in no more than 8 days in shake culture. Apodachlya brachynema was degraded in 8 days; $S$. diclina in 5 days, 
A. caroliniania in 7 days, $I$. luxuriana in 6 days, and $T$. clavata in 5 days. The mats in sterile sea water remained white, perfectly intact and viable.

These five fungi were then tested with the Agarbacterium sp. previously found capable of decomposing Pythium in sterile sea water. Washed mycelial mats were added to sterile sea water and an inoculum of $10^{6}$ bacteria $/ \mathrm{ml}$. was added. All five fungi were susceptible to lysis by this bacterium in no longer than 5 days. Traustotheca clavata, Saprolognia diclina and Apodachlya brachynema were completely degraded in 3 days; Isoachlya luxuriana in 4 days; and Achlya caroliniania in 5 days.

Thus it appears that there is a specific microflora which attacks the mycelial stage of these fungi in sea water. The same bacterial strain isolated from sea water was active against all of the fungi tested. These results indicate a close similarity in cell-wall structures of these fungi.

\section{DISCUSSION}

Large numbers of fungi have been isolated from the sea (Johnson \& Sparrow, I96I). We do not know if all these fungi grow actively in the sea, or if the isolates simply reflect survival of these fungi in the form of spores. We have observed that when Escherichia coli is added to sea water, an antagonistic marine microflora develops which kills that bacterium (Mitchell, Yankofsky \& Jannasch, 1967). In the current investigation, we present evidence that an antagonistic marine microflora also develops in response to the addition to sea water of the mycelial form of several Oomycetes.

The observation that the population size of the marine microflora affects the rate of kill of the fungus provides further evidence indicating the implication of a group of native marine micro-organisms in the eradication of Pythium debaryanum in the sea. The data showing that the rate of lysis of Pythium mycelium increases with each subsequent addition of the fungus to the same sample of sea water suggest the enrichment of a specific antagonistic group of micro-organisms or the increase in adaptive enzyme capacity or both.

We have reported previously the enzymic lysis of Pythium debaryanum in soil (Mitchell \& Hurwitz, 1965). It was not surprising, therefore, to find that culture filtrates of sea water contained enzymes capable of lysing Pythium following exposure of the sea water to mycelium of that fungus. We did not expect, however, that such large quantities of enzyme would be active in the sea water. Both enzymes (Mitchell \& Nevo, 1965) and Bdellovibrios (Mitchell et al. 1967) have been associated with the killing of Escherichia coli in sea water. Apparently, enzymic lysis of the cell walls is solely responsible for the decline of Pythium.

A similar susceptibility to lysis was detected when other non-marine Oomycetes were added to sea water. The observation that a marine isolated Pythium strain was equally susceptible to lysis suggests that fungi isolated from marine estuaries may not in fact, be ecologically restricted to the marine environment. Resistance to lysis by a marine microflora may be a useful tool in the characterization of a true marine mycoflora.

This study was supported in part by the Federal Water Pollution Control Administration Grant WP-00967, U.S. Department of the Interior. 


\section{REFERENCES}

COOPER, B. A. \& ARonson, J. M. (1967). Cell wall structure of Pythium debaryanum. Mycologia 59, 658.

Dische, Z. (1955). New color reactions for determination of sugars in polysaccharides. Meth. biochem. Analysis 2, 3 I3.

Johnson, T. W., Jun. \& Sparrow, F. K., Jun. (1961). Fungi in Oceans and Estuaries. Weinheim: J. Cramer.

Lyman, J. \& Fleming, R. H. (I940). Composition of sea water. J. mar. Res. 3, I 34.

MACLEOD, R. A. \& ONOFREY, E. (1963). Studies on the stability of the $\mathrm{Na}^{+}$requirement of marine bacteria. Symp. Marine Microbiol. Ed. by C. H. Oppenheimer. Springfield, Ill.: C. C. Thomas.

Mitchell, R. \& Alexander, M. (I963). Lysis of soil fungi by bacteria. Can. J. Microbiol. 9, i69.

Mitchell, R. \& Hurwitz, E. (I965). Suppression of Pythium debaryanum by lytic rhizosphere bacteria. Phytopathology 55, 156.

Mitchell, R. \& Nevo, Z. (1965). Decomposition of structural polysaccharides of bacteria by marine micro-organisms. Nature, Lond. 205, 1007.

Mitchell, R., YANKOFSKy, S. \& JANNASCH, H. W. (1967). Lysis of Escherichia coli by marine microorganisms. Nature, Lond. 215, $89 \mathrm{I}$.

OPPENHEIMER, C. H. \& ZoBell, C. E. (1952). The growth and viability of sixty-three species of marine bacteria as influenced by hydrostatic pressure. J. mar. Res. II, 10.

Raper, J. R. \& Hyatt, E. A. (I963). Modified press for disruption of micro-organisms. J. Bact. $85,712$.

ZoBell, C. E. (1946). Marine Microbiology. Waltham, Mass.: Chronica Botanica Co. 